\title{
Reclassification of Bacteria of the Genus Protomonas Urakami and Komagata 1984 in the Genus Methylobacterium (Patt, Cole, and Hanson) Emend. Green and Bousfield 1983
}

\author{
I. J. BOUSFIELD* AND P. N. GREEN \\ National Collections of Industrial and Marine Bacteria Ltd., Torry Research Station, Aberdeen AB9 8DG, Scotland
}

\begin{abstract}
The genus Protomonas was proposed to accommodate certain bacteria previously classified in the validly published genus Methylobacterium. No evidence was presented to support the exclusion of these bacteria from the latter genus. Therefore, we propose that bacteria of the genus Protomonas be reclassified in the genus Methylobacterium.
\end{abstract}

The genus Protomonas was proposed recently by Urakami and Komagata (5) to accommodate pink-pigmented, facultatively methylotrophic bacteria (PPFMs) exemplified by "Pseudomonas extorquens." However, earlier studies (1) resulted in a proposal (2) to classify these organisms in the genus Methylobacterium. This proposal (2) has nomenclatural priority according to the International Code of Nomenclature of Bacteria (3). Furthermore, we believe that the description of the new genus Protomonas (5) is taxonomically unsound because it takes no account of the bacteria of the validly published genus Methylobacterium $(2,4)$.

We realize that the formal proposal (2) had not yet appeared when Urakami and Komagata (5) proposed the new genus Protomonas, but we dispute their assertion that "taxonomic studies of this group (the PPFMs) have not clarified its status . . ." In earlier work (1), we showed quite clearly the high phenetic similarity ( $95 \%$ in some cases) of the PPFMs to the type strain of Methylobacterium organophilum (strain NCIB 11278 [= ATCC 27886]), the type species of the genus Methylobacterium. We also made the overt suggestion that the genus Methylobacterium was the most appropriate place for the PPFMs (1). In view of this, we consider the omission of the type (or any other) strain of $M$. organophilum from the studies of Urakami and Komagata (5) and the absence of any mention of the genus Methylobacterium in their generic proposal to be major taxonomic deficiencies. Therefore, because Urakami and Komagata (5) present no evidence to support the exclusion of the PPFMs from the genus Methylobacterium, we propose the reclassification of the bacteria of the genus Protomonas Urakami and Komagata 1984, namely Protomonas extorquens (type and only species), in the genus Methylobacterium (Patt, Cole and Hanson) emend. Green and Bousfield 1983 as Methylobacterium extorquens comb. nov.

We thank Dorothy Jones for helpful advice during the preparation of this paper.

\section{LITERATURE CITED}

1. Green, P. N., and I. J. Bousfield. 1982. A taxonomic study of some Gram-negative facultatively methylotrophic bacteria. J. Gen. Microbiol. 128:623-638.

2. Green, P. N., and I. J. Bousfield. 1983. Emendation of Methylobacterium Patt, Cole and Hanson 1976; Methylobacterium rhodinum (Heumann 1962) comb. nov. corrig.; Methylobacterium radiotolerans (Ito and Iizuka 1971) comb. nov. corrig.; and Methylobacterium mesophilicum (Austin and Goodfellow 1979) comb. nov. Int. J. Syst. Bacteriol. 33:875-877.

3. Lapage, S. P., P. H. A. Sneath, E. F. Lessel, V. B. D. Skerman, H. P. R. Seeliger, and W. A. Clark (ed.). 1975. International code of nomenclature of bacteria 1975 Revision. American Society for Microbiology, Washington, D.C.

4. Skerman, V. B. D., V. McGowan, and P. H. A. Sneath. 1980. Approved lists of bacterial names. Int. J. Syst. Bacteriol. 30:225-420.

5. Urakami, T., and K. Komagata. 1984. Protomonas, a new genus of facultatively methylotrophic bacteria. Int. J. Syst. Bacteriol. 34:188-201.

* Corresponding author. 